\title{
Relevance of lodine Intake as a Reputed Predisposing Factor for Thyroid Cancer
}

\begin{abstract}
lodine is a trace element that is essential for the synthesis of thyroid hormone. Both chronic iodine deficiency and iodine excess have been associated with hypertrophy and hyperplasia of follicular cells, attributed to excessive secretion of TSH. This may be associated to thyroid cancer risk, particularly in women. Experimental studies have documented thyroid cancer induction by elevation of endogenous TSH, although in a small number of animals. lodine deficiency associated with carcinogenic agents and chemical mutagens will result in a higher incidence of thyroid malignancy. Inadequate low iodine intake will result in increased TSH stimulation, increased thyroid cell responsiveness to $\mathrm{TSH}$, increased thyroid cell EGF-induced proliferation, decreased TGF $\beta 1$ production and increased angiogenesis, all phenomena related to promotion of tumor growth. Epidemiological studies associating iodine intake and thyroid cancer led to controversial and conflicting results. There is no doubt that introduction of universal iodine prophylaxis in population previously in chronic iodine-deficiency leads to a changing pattern of more prevalent papillary thyroid cancer and declining of follicular thyroid cancer. Also anaplastic thyroid cancer is practically not seen after years of iodine supplementation. lodine excess has also been indicated as a possible nutritional factor in the prevalence of differentiated thyroid cancer in Iceland, Hawaii and, more recently, in China. In conclusion: available evidence from animal experiments, epidemiological studies and iodine prophylaxis has demonstrated a shift towards a rise in papillary carcinoma, but no clear relationship between overall thyroid cancer incidence and iodine intake. (Arq Bras Endocrinol Metab 2007;51/5:701-712)
\end{abstract}

Keywords: lodine; Thyroid cancer; lodine deficiency; lodine excess; Carcinogenic agents; Environmental effect

\section{RESUMO}

Relevância da Ingestão de lodo como Fator Predisponente ao Câncer de Tireóide.

O iodo é essencial para a síntese de hormônios tireóideos e tanto a deficiência crônica deste halogeno como o excesso nutricional de iodo levam a hiperplasia e hipertrofia dos elementos foliculares (por excesso de TSH). Esse fenômeno pode se associar a maior risco de câncer de tireóide, especialmente no sexo feminino. Estudos experimentais documentam indução de câncer de tireóide após prolongado excesso circulante de TSH, o qual induz aumento da proliferação celular medida por fator de crescimento epidermal (EGF), decréscimo de síntese de fator de transformação do crescimento (TGF $\beta$ 1) e aumento da angiogenese. Estudos epidemiológicos entre nutrição de iodo e câncer de tireóide são conflitantes. É, todavia, aceito que a correção de prévia deficiência de iodo com aporte nutricional adequado deste halogeno leva à maior prevalência de carcinoma papilífero (e decréscimo de carcinoma folicular). Em alguns países, o excesso de iodo foi apontado como causa aparente de maior prevalência de câncer de tireóide. Em conclusão: não existe uma relação causa-efeito entre iodo nutricional e prevalência de câncer de tireóide, e outros fatores intervenientes ambientais devem ser considerados. (Arq Bras Endocrinol Metab 2007;51/5:701-712)

Descritores: lodo nutricional; Câncer de tireóide; Deficiência de iodo; Excesso de iodo; Agentes carcinogênicos; Efeito ambiental

\section{revisão}

\author{
MEYER KNOBEL \\ Geraldo Medeiros-Neto
}

Thyroid Unit, Division of

Endocrinology and Metabolism,

Hospital das Clínicas (MK), and

Department of Internal Medicine

University of São Paulo Medical

School (GM-N), São Paulo, SP. 
$\mathrm{T}$ HYROID CARCINOMA IS THE MOST commonly encountered endocrine malignancy (1). Its incidence among all ages rose steadily in different countries in the last 10 years, whereas its mortality rates dropped (2). The declining mortality rates are largely due to early diagnosis and effective therapy applied at an early tumor stage when it is most amenable to surgery and 131I therapy. Those tumors have a marked variability in aggressiveness from highly differentiated papillary carcinomas with a good prognosis, if found and treated early, to undifferentiated anaplastic cancers occurring mainly in older people and with a poor prognosis (3).

Iodine is a trace element that is essential in the synthesis of thyroid hormones. Both chronic iodine deficiency and chronically high iodine intake have been associated with the development of goiter (i.e., hypertrophy and hyperplasia of the thyroid cells) and attributed to excessive secretion of TSH by the pituitary. In turn, goiter has been associated with thyroid cancer risk, particularly in women (4).

A clear relationship between iodine supply to the population and thyroid cancer incidence has not been proven and is still debated (3). In general, chronic iodine deficiency and residence in an endemic goiter area are associated with an increased risk of follicular histological type of cancer, whereas chronically high iodine intake may increase the risk of the more common papillary histological type of thyroid cancer.

This outline summarizes available data from animal experiments, epidemiological studies and from the introduction of iodine prophylaxis on the possible association between iodine deficiency and the development of differentiated thyroid carcinoma.

\section{EXPERIMENTAL INDUCTION OF THYROID TUMORS}

Thyroid neoplasia may be induced by exposure of experimental animals to a variety of treatment regimens, exogenous chemicals or physical agents.

\section{Tumor induction by elevation of TSH}

It has been recognized for some time that neoplasms induced in experimental animals by a number of treatments result in thyroid gland dysfunction, more frequently hypothyroidism.

Among the thyroid cancer-causing factors inducing a hypothyroid state are iodine deficiency $(5,6)$ and subtotal thyroidectomy (7). In addition, thyroid tumors can result from the transplantation of TSH-secreting pituitary tumors (7-9). The one factor common to each of these conditions is that they all lead to increased production of TSH and prolonged stimulation of the thyroid gland by continuously elevated serum TSH. In the first two conditions, elevated TSH results from chronic stimulation of the pituitary in response to a deficiency in the circulating levels of thyroid hormone. It is worth mention note that nothing has been administered to these animals. Therefore the tumors developed in the absence of factors that are normally present in the animals (i.e., iodine and thyroid gland mass). It should rightfully be pointed out, however, that the animals were under chronic stress due to deficiency of thyroid hormone. In the third case, excess TSH comes from the transplanted pituitary tumor. Thus, irrespective of the cause, it appears that prolonged stimulation of the thyroid pituitary that results in release of elevated levels of TSH by the thyrotrophs may lead to thyroid gland neoplasia (10).

\section{Tumor induction by low iodine intake}

The hypothesis of an association between iodine intake and the risk for thyroid cancer is based on the results of studies in experimental animals, which showed that animals on an iodine-restricted diet were more likely to develop cancer $(6,11)$. On this basis, overstimulation by thyroid-stimulating hormone (TSH) was considered to play a major role in tumorigenesis. At variance, recent studies have shown, however, that the serum levels of TSH are in fact lower in individuals with mild-moderate iodine deficiency (12).

In golden hamsters submitted to long-term low-iodine diet, it has been experimentally shown hyperplasia, then nodular goiter and, eventually, in a small percentage of animals, carcinomas. The spontaneous malignancies reported in the iodine-deficient animals were follicular adenocarcinomas; $18 \%$ of females, but no thyroid lesions were found in males after a 70-week iodine-deficient diet. (11).

$\mathrm{C} 3 \mathrm{H} / \mathrm{Hey}$ strain-mice where placed in lowiodine diet to induce benign and malignant thyroid tumors. After one year of this nutritional condition, follicular adenomas developed in $60 \%$ and follicular carcinomas became manifest in $10 \%$ of the animals (6).

Male Sprague-Dawley (Han:SPRD) rats submitted to chronic iodine deficiency induced by a long-term iodine intake of approximately $10 \%$ of the normal iodine dietary supply developed follicular hypertrophy and subsequently follicular cell hyperplasia and thyroid hypertrophy (13). Iodine supplementation to approximately 16 times the normal concentration lead to hyperplasia of follicular cells, organ hypertrophy and a massive increased proliferation rate. Interestingly, the high proliferation rates did not induce any malignant changes. 
The risk that a benign thyroid tumor may develop after iodine deficiency or excess is 2- to 3 -fold higher than in controls. It was suggested that under the experimental conditions both long-term iodine deficiency and excess are insufficient to stimulate carcinogenesis, whereas benign tumors, detectable in approximately $90 \%$ of the animals after 110 weeks of treatment, were clearly more frequently found as compared to the control group with normal iodine supply. It seems that previous studies contradict these data $(5,14)$.

Iodine-deficient Fisher rats were shown to develop chromosomal abnormalities (aneuploidy) of some heterogeneous thyroid cell population. These cells may have acquired neoplastic characteristics, for when such a cell population is transplanted, a neoplastic tumor is produced (15).

\section{Studies with combination of tumor-inducing factors}

Several investigations have indicated that combined treatment regimens are associated with thyroid carcinogenetic responses in excess of that produced by either single treatment alone.

A few direct acting exogenous chemical compounds have been identified that produce thyroid tumors that do not appear to influence the thyroidpituitary status, as these compounds did not increase thyroid weights unrelated to tumor development or cause a persistent elevation of serum TSH levels (16). Two of them are $\mathrm{N}$-nitrosomethylurea (NMU) and Nbis(2-hydroxypropyl)-nitrosamine (DHPN), classified as genotoxic, since involves direct carcinogenic effects at the DNA level in follicular cells.

Non-genotoxic agents, as iodine, may alter the negative feedback system of the thyroid-pituitary hypothalamus axis, leading to TSH increase and its prolonged stimulation of follicular epithelium (17) as already mentioned.

The thyroid combined treatment studies are consistent with the concepts of initiation-promotion. The genotoxic agent might permanently alter the thyroid cell so that its accentuated growth under a goitrogenic stimulus would result in neoplasms (6).

Rats previously treated with NMU and then placed on an iodine-deficient diet, had increased incidence of thyroid follicular cell carcinomas $(90 \%)$ in comparison to $10 \%$ of rats exposed to iodine deficiency alone. On the other hand, about $20 \%$ of the rats developed follicular carcinomas when treated with the same carcinogen, but in normal conditions for iodine nutrition. These observations indicated that the iodine-deficient diet is a potent promoter of thyroid tumors initi- ated by NMU and also a carcinogen by itself (18). Moreover, the results suggested that the non-genotoxic component, i.e., elevation of TSH, plays a key role in the development of thyroid lesions (19).

In another study, F344 rats were given the chemical mutagen DHPN and supplemented with various amounts of potassium iodide in drinking water to generate conditions that extended to chronic iodine deficiency to severe iodine excess. In DHPN-treated rats, both conditions significantly increased thyroid follicular tumorigenesis. In DHPN-untreated rats, iodine deficiency produced diffuse thyroid hyperplasia, together with a decrease in serum thyroxine and an increase in serum TSH. On the other hand, iodine excess produced colloid goiter, together with normal serum T4 and slightly decreased TSH. Under influence of DHPN there was a rapid rise in tumor incidence with increasingly low levels of dietary iodine. Interestingly, in this study there was a slight rise in tumor incidence at high iodide levels. These effects were directly proportional to the severity of iodine deficiency or extent of iodine excess and suggest that each condition has a different thyroid tumor promotion mechanism (20) (figure 1).

In rats, iodine deficiency is much more effective as a tumor promoter as compared to its carcinogenic effect, suggesting that a similar relationship may exist in human populations. However, it should be emphasized that data from animal studies in relation to thyroid tumors may not be extended to human thyroid.

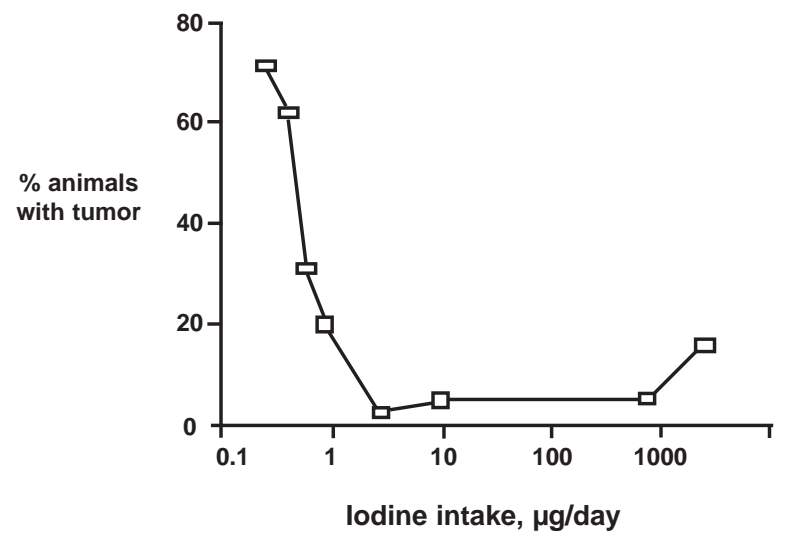

Figure 1. In this experimental study conducted by Kanno et al. (20), tumor-promoting effects were observed clearly in iodine deficiency, when using a chemical carcinogen. Data includes adenomas and carcinomas of the thyroid. Note, however, that animals fed excessive nutritional iodine had an increase in tumor prevalence. 
In the former, thyroid tumors can be reproduced precisely and studied exactly, but the relevance of these tumors to human lesions is doubtful since they show a pattern of morphology and behavior that is strictly different from human tumors.

\section{CELL BIOLOGY OF THYROID CARCINOGENESIS}

Thyroid carcinogenesis is a multi-stage phenomenon and is considered to involve basically an oncogene mutation, response to growth factors and the clonality of the neoplastic tissue architecture (21). All conditions that favor prolonged stimulation of cell proliferation are apt to facilitate pre-malignant transformation. The increased number of cell division gives to protooncogenes an enhanced probability to be activated and to oncosuppressor genes to be damaged (22).

The characteristic feature of malignancy is an increased growth rate of the cell, and the development of a tumor can be thought of as a series of steps, each marked by the growth of a clone with higher growth rate than the rest of the lesion. Moreover, the importance of post-mutagen growth in the thyroid is well shown by two observations: a) there is a great increase in incidence of rodent thyroid tumors if TSH is elevated by goitrogen treatment or by a low-iodide diet after mutagen administration, as DHPN or NMU, and b) thyroid carcinogenesis is abolished if suppressive thyroxine treatment or hypophysectomy is used immediately after mutagen exposure preventing any TSHinduced growth $(23,24)$.

Unlike many other highly specialized cells, thyroid cells are not irreversibly terminally differentiated. When they proliferate in response to certain growth signals they temporarily lose the ability to concentrate iodide and to synthesize thyroglobulin. Certain unregulated growth signals associated with malignant transformation may contribute to the loss of differentiated thyroid function. The thyroid cell turns over, on average, no more than five times through adulthood (25). Turnover increases in early infancy and adolescence $(25,26)$. Because of the homogeneity of the growth potential of follicular cells (27), a fraction of these follicular cells in adults would likely turnover much more than five times. It is assumed that cycles of cell division may be more frequent in benign or malignant tumors $(27,28)$, although evidence from human tumors does not always support this notion (29).

An understanding of the factors involved in normal human thyroid cell growth, differentiation, and signaling is an essential prelude to understanding aberrations related to thyroid cell transformation. Unfortunately, the picture is incomplete due to the variability among species of factors that sustain thyroid proliferation and the pathways used (30). Growth factors also play a key role, along with TSH, in the complex regulation of thyroid cell proliferation, but there are few data yet to explain how these trophic factors interact with the cell cycle to stimulate or inhibit cell division in the thyroid.

A variety of mechanisms cooperate to determine thyroid cell stimulation to proliferate in conditions of chronic iodine deficiency (31).

\section{Increased TSH stimulation}

Thyrotropin, through activation of its receptor, has been shown to stimulate more than one signal transduction pathway in the regulation of both growth and differentiated function. Each pathway may be related to specific cellular events. The main effector of TSH on proliferation and differentiation in a variety of species, humans and rats included, is the cAMP signal transduction pathway, that is, the cascade involving activation of adenylate cyclase resulting in CAMP generation (33).

Evidence concerning the mitogenic role of TSH for thyroid cells in vivo has been further consolidated over recent years. Studies from various laboratories using tritiated thymidine labeling, metaphase arrest techniques for mitotic index, or immunohistochemical decoration of statin (a non-proliferation-specific nuclear antigen identifying quiescent $G_{o}$-phase cells) show that TSH stimulates, in a dose- and timedependent way, the recruitment of noncycling $G_{o}$ cells into the cycling compartment, as well as entry into $S$ phase and the entry of $\mathrm{G}_{2}$ cells into mitosis (32).

Recent work has indicated that the normal rodent (and human) thyroid may have an intrinsic heterogeneity in the follicular cell population regarding the capacity for proliferative response to TSH. One hypothesis suggests that there are a few subsets of stemlike follicular cells with a high growth potential compared to the majority of the population and that this trait is stable and heritable (34). According to this model, the clones of cells with extensive proliferative potential are the origin of the adenomas that develop under conditions of chronic TSH stimulation (35).

As proposed by Studer et al. (27), the above intrinsic stem cell clone model reconciles earlier kinetic observations $(36,37)$ that hyperstimulated thyroid attains a plateau phase of growth or state of "desensitization", with the vast majority of follicular cells becoming refractory to the mitogenic effects of increased TSH levels before the emergence of adenomas. In this model, chronic TSH stimulation would 
select preexisting thyrocyte clones with the greatest proliferative potential and thus with the greater risk of neoplastic transformation. An alternative model for explaining the self-limited nature of hyperthyroidism and the development of hormone-responsive tumors in the chronically stimulated rat thyroid proposes that clones of cells escape from the desensitization mechanism through mutational events and natural selection, leading ultimately to tumor formation (19). Both models agree that thyroid carcinogenesis involves rare subsets of cells responsive to continued TSH stimulation but differ concerning the origin of follicular cell heterogeneity. Additional support for the intrinsic subset concept and/or the controlling influence of TSH on the development of selected clones of thyroid follicular cells comes from other studies on cell proliferation (33) and from those using transplantation methodology (38).

The impaired synthesis of thyroid hormones, due to the iodine shortage, will result in (subclinical) hypothyroidism and increased TSH secretion. TSH induces human thyroid cell growth at a higher concentration than is necessary for induction of differentiated function (39).

\section{Increased thyroid cell responsiveness to TSH}

Iodine deficient thyroid cells will have an increased content of the two major intracellular messengers for the TSH signaling pathways, cAMP and $\mathrm{Ca}^{++}$(39). Under this condition, the thyroid cell is sensitized to TSH stimulation, which elicit responses that are inappropriately high for a given stimulation.

There is evidence that iodine is a major mediator of thyroid autoregulation, involving numerous inhibitory actions (41). One of these is a decrease in cAMP formation in response to TSH, resulting in an inhibition of all cAMP-mediated stimulatory effects of TSH on the thyroid. Excess iodide therefore exerts a negative control on different thyroid parameters, inhibiting iodide uptake and organification, protein and RNA biosynthesis, hormone secretion, as well as paracrine mitogenic activity on endothelial cells and fibroblasts (42).

Most of these actions appear to be mediated by an intracellular organified iodine intermediate of unknown identity. Various derivatives of arachidonic acid have been proposed as this putative regulator(s), including the iodinated eicosanoid, delta-iodolactone (42).

The iodolactone growth inhibitory mechanism, which is decreased in iodine-deficient thyroid cells, is believed to occur via inhibition of the specific EGFdependent production of IP3, a signal transducer that modulates thyroid cell proliferation (43). However, this compound had no effect on TSH-mediated cAMP formation in porcine follicles (43). Considered to be a more likely candidate is 2 -iodohexadecanal (44), a major iodolipid formed in horse thyroid when incubated with iodide (45), but which is also detectable in the thyroid of other species, including humans and rats.

Increased thyroid cell EGF-induced proliferation Growth factors also play a key role, along with TSH, in the complex regulation of thyroid cell proliferation, but there are few data yet to explain how these trophic factors interact with the cell cycle to stimulate or inhibit cell division in the thyroid.

These autocrine/paracrine regulators of thyroid growth, with potent mitogenic activity for thyroid cells demonstrable in vitro, include epidermal growth factor (EGF) and basic fibroblast growth factor (bFGF). EGF is synthesized within the thyroid gland and induces proliferation in thyroid cells from a wide range of species at the expense of dedifferentiation and loss of specialized thyroid-specific function (46). Over expression of EGF and GF-receptor in RNAS were detected in dyshormonogenetic goiters that were under constant and prolonged endogenous TSH stimulation (47). Basic FGF (fibroblast growth factor) is present in human thyroid tissue (48) and there are stores of FGF in the basement membrane of follicles in normal adult rat thyroid (49). Moreover, bFGF expression increases during thyroid hyperplasia in rodents $(50)$.

EGF has been shown to stimulate the growth and invasion of differentiated human thyroid cancer cells in culture and in nude mice (51). In some tissue culture systems TSH does not stimulate thyroid cell growth unless other growth factors as EGF are present (52). EGF binding in thyroid neoplasms is also somewhat higher than in normal thyroid tissue from the same patients (53).

\section{Decreased TGF $\beta$ production}

Transforming growth factor $\beta 1$ (TGF $\beta 1$ ) is a putative negative regulator of thyroid growth, as studies in normal cell systems have shown it to inhibit thyrocyte proliferation, including that mediated by TSH (54). Although the actual role of TGF $\beta 1$ in the thyroid is not known, cell culture and rodent investigations suggest that it is a limiting autocrine influence on thyroid cell hyperplasia, cancer growth and invasion (55). In one study, TGF $\beta 1$ was detected in approximately $50 \%$ of human thyroid carcinomas, but not in adenomas, with 
a striking correlation being observed between the dual presence of TGF $\beta 1$ expression and arginine substitution at codon 61 of the H-ras oncogene (56). Lazzereschi et al. (57) demonstrated a significant reduction of TGF $\beta$ receptor type II mRNA and protein expression in thyroid carcinomas but found no reduction in thyroid adenomas. These studies suggest that escape from the growth inhibitory effect of TGF $\beta 1$ may play an important role in the progression of human thyroid cancer.

Iodine increases the thyroid production of TGF $\beta 1$ (58), a process that is related to iodine organification. Iodine deficiency, therefore, may result in a decrease of thyroid cell growth negative regulation.

\section{Increased angiogenesis}

Iodine deficiency causes thyroid enlargement (goiter), which is characterized also by formation of new vessels. The factors regulating angiogenesis in thyroid are not yet well established. Many of the factors elaborated by the thyroid, e.g., IGF-I (59) and FGF (60), also act in vivo on endothelial cells to induce neovascularization (59) and to enhance adhesion molecule synthesis to support thyroid growth. Data from animal thyroid tissue support the hypothesis that capillary growth during thyroid enlargement occurs, at least in part, as a result of a parenchymal-stromal (epithelial-mesenchymal) paracrine interaction mediated by specific endotheliotropic (angiogenic) factors released by follicular epithelial cells (62). FGF is also a potent thyroid cell mitogen (63). In agreement, serum vascular endothelial growth factor (VEGF) is significantly elevated in patients with metastatic differentiated thyroid cancer but not in those with poorly differentiated thyroid cancer metastases (64). Furthermore, in hypothyroid subjects, serum VEGF levels correlate with TSH values $(65)$.

Thus, the proposed mechanisms implicating growth factors associating low iodine intake to thyroid carcinogenesis can be summarized as follows:

- Increased TSH stimulation: low T4 synthesis associated to higher TSH secretion will promote follicular cell proliferation

- Thyroid cell responsiveness to TSH: is increased in iodine deficient thyroid cell (increased $\mathrm{Ca}^{++}$and cAMP pathways)

-Increased thyroid cells EGF-induced proliferation: decreased intracellular organified iodine intermediate (iodolactone or 2-iodohexadecanal) will result in EGF-induced cell proliferation

- Decreased TGF $\beta$ production: thyroid cell proliferation is inhibited by TGF $\beta$. Iodine deficiency will result in a decrease of growth negative regulation

- Increased angiogenesis: may promote tumor growth.

\section{EPIDEMIOLOGICAL STUDIES, RELATIONSHIP BETWEEN IODINE INTAKE AND THYROID CANCER HISTOTYPES}

Thyroid carcinoma is an infrequent tumor with geographic variation in its prevalence. Papillary carcinoma accounts for $85-90 \%$ of differentiated thyroid cancers in iodide-sufficient countries (66), while the remaining epithelial thyroid cell tumors are predominantly follicular carcinomas. Anaplastic carcinoma, whose incidence has been decreasing, often arises from preexisting welldifferentiated (usually follicular) carcinoma (67).

Epidemiologists search for clues to causes of disease and to factors that increase an individual's risk of disease (risk factors) by examining descriptive data or designing analytic studies. Descriptive data consist of morbidity, mortality or incidence rates of diseases in population groups. Incidence rates (newly diagnosed cases in a population over a given time period) reveal patterns of disease by age, race, sex, ethnic group and geographic localization. Those rates and their changes over time identify high-risk groups and provide indirect evidence for causes of disease. Analytical epidemiology consists of case control, often termed retrospective and cohort or prospective studies. These studies permit greater control of confounding factors and an opportunity to link exposure and response information in individuals. Thus, evidence for causes of disease is more direct.

Numerous studies have been carried out in the populations of distinct geographical areas known to have different iodine intake and in the same area, before and after changes in population iodine intake, in order to evaluate the discrepancies in the prevalence of thyroid cancer. Most of them, however, are considered to be biased by either ethnic differences in the studies populations and also by environmental factors, other than iodine deficiency, that may also influence thyroid tumorigenesis, like exposure to radiation, goitrogens or diet. The distinct procedures used by the investigators for both surveying cancer and evaluating iodine deficiency may also have affected the results obtained.

The epidemiologic approach to investigating whether goiter leads to thyroid cancer in humans is based in the following procedures:

1.examine descriptive data

2.compare the thyroid cancer rates between endemic goiter areas and goiter-free areas

3.examine time trends for thyroid cancer after prophylactic measures (iodine supplementation) reduce endemic goiter frequency in a given area, and 
4.evaluate whether goitrous individuals have a greater risk of thyroid cancer or whether thyroid cancer cases have a more frequent history of hyperplasia and nodules than controls.

Clinically evident thyroid nodules and benign goiters occur frequently in iodine-deficient areas. A population-based study carried out in Sicily in two adjacent areas with different iodine intake but similar ethnic and life-style characteristics, first surveyed cold thyroid nodules and then using fine needle aspiration and cytology which percentage of cancer occurred among the cold nodules in two populations (68). This study indicated that the risk of thyroid cancer is increased (relative risk $=1.4$ ) in the population living in the iodine deficient area.

The relationship of thyroid cancer to endemic goiter is widely accepted $(69,70)$. In agreement, it was found a geographical correlation between endemic areas for goiter and thyroid cancer. A higher incidence of thyroid cancer was found in England, Wales and Switzerland in areas with endemic goiter $(70,71)$. However, no association was found in the United States between goitrous and non-goitrous areas (72). Another study performed in Nordic countries as Finland, Iceland, Norway and Sweden over periods ranging from 1 to 14 years found no association between the presence of endemic goiter and the risk of follicular carcinoma. Further, there was a marked negative association between endemic goiter and the risk of papillary carcinoma $(73)$.
The search for a similar relationship between the occurrence of malignant thyroid tumors and iodine intake has been controversial and with conflicting results.

The overall incidence of thyroid carcinoma is generally considered without influence from the iodine intake in a given population (3), although a study from two regions in Italy has recently demonstrated a two-fold increase in thyroid cancer incidence in an iodine-deficient area compared to an iodine-sufficient one (68). Contrary to this, some of the highest incidence rates of thyroid cancer are found in Iceland (74) and Hawaii (75) (table 1), both known to have long-standing high iodine intake, although exposure to volcanic activity (where the natural radiation is higher and radiation is known to increase the development of thyroid carcinomas) has been suggested as an explanation for the high incidence in these islands.

Very recently, another study compared the thyroid cancer incidence by morphological subtypes in the eastern (with mild iodine deficiency) and western (with moderate iodine deficiency) Denmark, in the period of 1973- 1997. No regional difference was found in the overall incidence of follicular or papillary thyroid cancer (76).

Overall the above data indicate that:

- nutritional iodine intake and incidence of cancer remains a controversial issue

- there is a weak evidence that low iodine intake would increase the temporal incidence of thyroid malignancy in a given population

Table 1. lodine-rich areas and incidence of thyroid cancer.

\begin{tabular}{lccc}
\hline Country* (year) & $\begin{array}{c}\text { Thyroid cancer after } \\
\text { surgery }\end{array}$ & $\begin{array}{c}\text { Incidence rate } \\
\mathbf{1 0 5} \text { inhabitants (\%) }\end{array}$ & Reference \\
Iceland (1977) & 186 & 6.0 & 74 \\
Hawaii (1988) & 1472 & $8.1 \%$ & 75 \\
& & $3.10^{*}$ & \\
\hline
\end{tabular}

* Both countries have a very high iodine intake through seafood.

Table 2. Changing incidence of thyroid cancer in Tasmania during transition from iodine sufficiency to iodine deficiency: histologic types.

\begin{tabular}{lcccc}
\hline Years & $\begin{array}{c}\text { mcg of iodine } \\
\text { excreted/gram } \\
\text { of creatinine* } \\
\text { (median) }\end{array}$ & Papillary & Follicular & Ratio PTC/FTC \\
\hline $1978-1984$ & $<75$ & 27 & 20 & 1.35 \\
$1985-1991$ & $<75$ & 43 & 21 & 2.04 \\
\hline $1992-1998$ & 42 & 110 & 26 & 4.23 \\
\hline
\end{tabular}

Optimal iodine intake: $120-200 \mu \mathrm{g}$ of iodine/gram of creatinine. [adapted from ref. 78] 
- high iodine intake, however, is also associated with an increased incidence of thyroid cancer (other environmental factors may be present).

Differences in iodine intake also affect the distribution of morphological subtypes of thyroid cancer, although the findings are also equivocal.

It has been hypothesized that iodine deficiency causes a high incidence of follicular tumors and that iodine supplementation shifts the distribution towards papillary tumors, as observed in Switzerland (70), Germany (77) and in Austria (78) (figure 1).

A study in Tasmania during a period when iodine intake changed from sufficient to deficient (1978-1998) showed a similar trend, although this followed a period of iodine supplementation, which complicates the interpretation (79) (table 2).

In a Swedish study, papillary thyroid cancer was commoner in iodine-rich areas, and follicular cancer was more common in iodine-depleted areas. After an iodine supplementation program, the incidence of papillary cancer rose and that of follicular cancer fell, but these trends were the same in both areas, and thus unrelated to the supplementation program (80). These inconsistencies in the results of these studies might be explained by different causation patterns for the different histological subtypes. In line with this argument, a case control study in Sweden of 484 cases of thyroid cancers during 1980-1992 (80) showed that the length of residence in an iodine-deficient area where goiter had been endemic was most strongly associated with an increased risk of thyroid follicular cancer $(\mathrm{RR}=1.3-1.5)$. Moreover, for papillary cancer, an increased risk (RR) to 2.5 was observed only for women exposed to iodine-deficiency during puberty (81). Overall there remains a general view that no convincing evidence has yet emerged to link environmental thyroid cancer with areas of iodine deficiency $(82-84)$. In a recent study on the effect of iodine intake on thyroid diseases in China, three representative communities, respectively with deficient iodine intake (A), normal iodine intake (B) and excessive iodine intake (C), were surveyed for thyroid diseases in a period of five years. No cases of thyroid cancer were identified in areas $\mathrm{A}$ and $\mathrm{B}$ but, at baseline, 10 patients with thyroid cancer were identified in the area $\mathrm{C}$ (excessive iodine intake). Moreover 13 new cases of thyroid cancer were diagnosed in this area $\mathrm{C}$ but none were found in the two other regions (A, B). Although this study has some limitations, it points to the fact that excessive iodine intake may be linked to a higher prevalence of thyroid cancer as compared to populations with low or adequate Iodine nutrition (85). More recently, Camargo et al. (86) studied urinary excretion of iodine, thyroid function tests, thyroid antibodies and sonographic characteristics of 829 inhabitants of a suburban area of great São Paulo city. This population had been on excessive iodine intake (59.5\% excreted more than $300 \mu \mathrm{g}$ Iodine/L of urine) for six years (1998-2003). Although there was an increase in prevalence of autoimmune thyroiditis (17.9\%), 18 nodules $(2.18 \%)$ were considered suspicious for malignancy (none have yet been submitted to surgery). In order to reach a conclusion about excessive intake and thyroid cancer it would be necessary to follow-up subjects with nodules form this population for at least two more years and to obtain histological evidence (after surgery) for suspicious nodules.

There is also some further evidence that has come from studies in areas with previous iodine deficiency before and after iodine prophylaxis, that the incidence rates of the type of thyroid carcinoma may be changing. In one such study from an area in Argentina (82), the ratio of papillary to follicular carcinomas rose from 1.7:1 to 3.1:1 (table 3).

Another study demonstrated that the histopathological types of thyroid cancer are different in iodine deficient areas and iodine sufficient ones (83).

A striking difference in the relative prevalence in the thyroid cancer histotypes was also observed in the two adjacent areas of Sicily (68) with different iodine intake (table 4 ) indicating that even moderate iodine deficiency is associated with an increased frequency of more aggressive histopathological types of thyroid cancer. However, it should be emphasized that the longstanding program of supplementation of food items with iodine in Sweden has not affected thyroid cancer trends in iodine-deficient or iodine-rich areas (80).

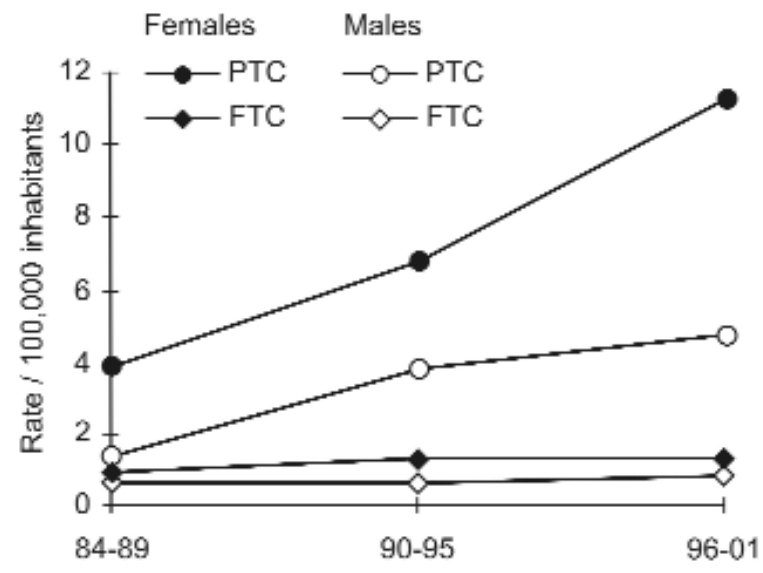

Figure 2. Thyroid carcinoma age standardized incidence rate by histological types in Carinthia, Austria, 1984-2001, in males and females, according to iodine supply; PTC: papillary thyroid cancer; FTC: follicular thyroid cancer. [Adapted from ref. 78] 
Table 3. Frequency of thyroid cancer by tumor type in Salta, Argentina, before and after iodine supplementation.

\begin{tabular}{lcc}
\hline & $\begin{array}{c}\text { Period of study of pathological specimens } \\
\text { (years after iodine }\end{array}$ \\
Total numberementation)
\end{tabular}

Adapted from ref. 82.

Table 4. Histologic pattern of thyroid tumors in two areas of Sicily, Italy, with low and adequate iodine intake.

\begin{tabular}{|c|c|c|}
\hline Histology & $\begin{array}{c}\text { lodine deficient area** } \\
\text { (Northeastern: } \\
18.9-43.2 \mu \mathrm{g} / \mathrm{l} \text { ) }\end{array}$ & $\begin{array}{l}\text { lodine sufficient area* } \\
\text { (Catania: } 114 \pm 8.4 \mu \mathrm{g} / \mathrm{l})\end{array}$ \\
\hline $\begin{array}{l}\text { Total patients examined } \\
\text { (submitted to surgery) }\end{array}$ & $911(126)$ & 2437 (419) \\
\hline Papillary & 11 & 103 \\
\hline Follicular & 11 & 27 \\
\hline Anaplastic & 5 & 9 \\
\hline Incidence $\times 10^{5}$ inhabitants & 1.27 & 0.93 \\
\hline
\end{tabular}

Adapted from ref. 68 .

An alternative explanation for the observed increase in the number of papillary cancers could be the introduction and wider use of more modern and precise examination equipment through the years, as the reversal of iodine deficiency coincides with the dissemination of better techniques in the health system, including thyroid scintigraphy, ultrasound and fineneedle biopsy. Furthermore, in areas without iodine deficiency, and hence less goiter, patients are more likely to notice a slight change in their thyroid gland and visit their doctor for examination (3). Autopsy studies support the possibility of a pool of slowly growing, undiagnosed papillary thyroid tumors (84).

The importance of accurate histological typing in cancer epidemiology cannot be overemphasized, and great caution is needed in comparison of different types of thyroid tumors in different populations if not evidenced by the same pathologist. The reproducibility of the WHO classification has been questioned and a considerable observer variation has been reported, particularly as regards to follicular and mixed papillary-follicular cancers (87). Differences in the detection and inclusion of occult thyroid cancers in the studies could also play a role in the observed cancer incidences. Finally, it should be noted that a concomitant selenium defi- ciency in iodine-deficient areas has not been taken into account, since selenium (Se) deficiency in itself has recently been associated with an increased incidence of thyroid carcinoma, based on converging data from epidemiological and clinical studies (88). Other studies, however, failed to find links between Se and thyroid carcinogenesis (89). To our knowledge, up to now there are no reliable experimental data that supports the plausibility of Se as a risk factor in thyroid cancer.

All of the above reservations are probably reasons why comparison of thyroid carcinoma epidemiology in different populations and geographic areas are so difficult to perform and interpret, and why no specific solutions to the questions concerning environmental influence of iodine intake have been provided, despite a large number of studies over many years.

Thus, regarding iodine prophylaxis and variations on thyroid cancer incidence, the data indicate that: - After iodine prophylaxis it has been demonstrated a clear relationship between increased iodine nutrition and elevation of the PTC/FTC ratio

- This has occurred even in modest increases in iodine urinary excretion

- A decrease in prevalence of anaplastic thyroid cancer was also observed in most areas. 


\section{CONCLUSION}

Available evidence from animal experiments, epidemiological studies and from the introduction of iodine prophylaxis has demonstrated a relationship between iodine intake and the types of thyroid carcinoma, while no clear evidence exists for a relationship between the overall cancer incidence and iodine intake. All the studies are in general hampered by difficulty in comparing populations since many factors have to be considered other than the iodine intake, such as ethnicity, other dietary factors (e.g., selenium), histological examination and radiation. Knowledge of all these factors has an influence also on the diagnostic work-up and management of patients in each population.

\section{REFERENCES}

1. Parkin DM, Muir CS, Whelan SL, et al. Cancer incidence in five continents. IARC Sci Publ 1992;(120):984-7.

2. Whelan SL, Parkin DM, Masuyer E. Patterns of cancer in five continents. IARC Sci Publ 1990;102:152-3.

3. Feldt-Rasmussen $U$. lodine and cancer. Thyroid 2001;11:483-6.

4. Horn-Ross PL, Morris JS, Lee M, West DW, Whittemore AS McDougall IR, et al. lodine and thyroid cancer risk among women in a multiethnic population: the Bay Area Thyroid Cancer Study. Cancer Epidemiol Biomarkers Prev 2001:10:979-85.

5. Axelrad AA, Leblond CP. Induction of thyroid tumors in rats by low-iodine diet. Cancer 1955;8:339-67.

6. Schaller RT, Stevenson JK. Development of carcinoma of the thyroid in iodine-deficient mice. Cancer 1966;19:1063-80.

7. Dent JN, Godsden EL, Furth J. Further studies on induction and growth of thyrotropic pituitary tumors in mice. Cancer Res 1956;16:171-4.

8. Haran-Guera N, Pullar P, Furth J. Induction of thyrotropindependent thyroid tumors by thyrotropes. J Endocrinol 1960:66:694-701.

9. Sinha D, Pascal R, Furth J. Transplantable thyroid carcinoma induced by thyrotropin. Arch Pathol 1965;79:192-8.

10. Williams ED. TSH and thyroid cancer. Horm Metab Res Suppl 1990;23:72-5.

11. Fortner JG, George PA, Sternberg SS. Induced and spontaneous thyroid cancer in the Syrian (golden) hamster. Endocrinology 1960;66:364-76.

12. Laurberg $P$, Nohr SB, Pedersen KM, Hreidarsson AB, Andersen S, Bulow Pedersen I, et al. Thyroid disorders in mild iodine deficiency. Thyroid 2000;10:951-63.

13. Boltze C, Brabant G, Dralle H, Gerlach R, Roessner A, HoangVu C. Radiation-induced thyroid carcinogenesis as a function of time and dietary iodine supply: an in vivo model of tumorigenesis in the rat. Endocrinology 2002;143(7):258492.

14. Correa $P$, Welsh RA. The effect of excessive iodine intake on the thyroid gland of the rat. Arch Pathol 1960;70:247-51.

15. Al-Saadi A. Precursor cytogenetic changes of transplantable thyroid carcinoma in iodine deficient goiters. Cancer Res 1968;28:739-45.

16. Hiasa Y, Kitahori $Y$, Konishi N, Ohshima M. Chemical carcinogenesis in the thyroid gland. Toxicol Lett 1992;64/65:389-95.

17. Hill RN, Erdreich LS, Paynter OE, Roberts PA, Rosenthal SL, Wilkinson CF. Thyroid follicular cell carcinogenesis: a review. Fundam Appl Toxicol 1989;12:629-97.
18. Ohshima M, Ward JM. Dietary iodine deficiency as a tumor promoter and carcinogen in male F344/NCr rats. Cancer Res 1986;46:877-83.

19. Thomas GA, Williams ED. Evidence for and possible mechanisms of non-genotoxic carcinogenesis in the rodent thyroid. Mutat Res 1991;248:357-70.

20. Kanno J, Onodera H, Furuta K, Maekawa A, Kasuga T, Hayashi $Y$. Tumor-promoting effects of both iodine deficiency and iodine excess in rat thyroid. Toxicol Pathol 1992;20:226-35.

21. Williams ED. Mechanisms and pathogenesis of thyroid cancer in animals and man. Mutat Res 1995;333:123-9.

22. Cohen SM, Ellwein LB. Cell proliferation in carcinogenesis. Science 1990;249:1007-11

23. Jemec B. Studies of the goitrogenic and tumorigenic effect of two goitrogens in combination with hypophysectomy or thyroid hormone treatment. Cancer 1980;45:2138-48.

24. Nadler NJ, Mandavia M, Goldberg M. The effect of hypophysectomy on the experimental production of thyroid neoplasms. Cancer Res 1970;30:1909-11.

25. Coclet J, Foureau F, Ketelbant P, Galand P, Dumont JE. All population kinetics in dog and human adult thyroid. Clin Endocrinol (Oxf) 1989;31:655-65.

26. Conde E, Martin-Lacave I, Utrilla JC, Moreno A, GonzalesCampora R, Galera-Davidson H. Mitotic activity of the endocrine cells in rat thyroid glands during postnatal life. Endocrinology 1992;131:436-40.

27. Studer H, Peter HJ, Gerber H. Natural heterogeneity of thyroid cells: the basis for understanding thyroid function-and nodular goiter growth. Endocr Rev 1989;10:125-35.

28. Knobel M, Bisi H, Peres CA, Medeiros-Neto G. Studies on functional and morphological aspects in human multinodular simple goiter tissues. Endocr Pathol 1993;4:205-14.

29. Dawson TP, Wyllie FS, Wynford-Thomas D. In vitro responsiveness to serum growth factors is inversely related to in vivo malignancy in human thyroid epithelial cells. Br J Cancer 1991;63:827-900.

30. Farid NR, Shi Y, Zou M. Molecular basis of thyroid cancer. Endocr Rev 1994;15:202-32.

31. World Health Organization, United Nations Children's Found and International Council for Control of lodine Deficiency Disorders; Elimination of iodine deficiency disorder (IDD) in Central and Eastern Europe, the Commonwealth of Independent States and the Baltic States. Proceedings of a conference held in Munich, Germany, 3-6 September 1997. WHO/Euro/NUT/98.1.

32. Dumont JE, Lamy F, Roger P, Maenhaut C. Physiological and pathological regulation of thyroid cell proliferation and differentiation by thyrotropin and other factors. Physiol Rev 1992;72:667-97.

33. Bayer I, Mitmaker B, Gordon PH, Wang E. Modulation of nuclear statin expression in rat thyroid follicle cell following administration of thyroid stimulating hormone. J Cell Physiol 1992; $150: 276-82$

34. Smeds S, Peter HJ, Jortso E, Gerber H, Studer H. Naturally occurring clones of cells with high intrinsic proliferation potential within the follicular epithelium of mouse thyroids. Cancer Res 1987;47:1646-51.

35. Groch $\mathrm{KM}$, Clifton $\mathrm{KH}$. The plateau phase rat goiter contains a sub-population of TSH-responsive follicular cells capable of proliferation following transplantation. Acta Endocrinol 1992;126:85-96.

36. Christov K. Cell proliferation kinetics and DNA content during thyroid carcinogenesis. Cell Tissue Kinet 1985;18:119-31.

37. Wynford-Thomas D, Stringer BMJ, Williams ED. Desensitization of rat thyroid to the growth-stimulating action of $\mathrm{TSH}$ during prolonged goitrogen administration. Persistence of refractoriness following withdrawal of stimulation. Acta Endocrinol 1982;101:562-9.

38. Domann FE, Mitchen JM, Clifton KH. Restoration of thyroid function after total thyroidectomy and quantitative thyroid transplantation. Endocrinology 1990;127:2673-8.

39. Roger PP, Dumont JE. Factors controlling proliferation and differentiation of canine thyroid cells cultured in reduced severe conditions: effects of thyrotropin, cyclic AMP and growth factors. Mol Cell Endocrinol 1984;36:79-93. 
40. Corvilain B, Laurent E, Lecomte M, Vansande J, Dumont JE. Role of the adenosine $3^{\prime}, 5^{\prime}$-monophosphate and the phosphatidylinositol- $\mathrm{Ca}^{2+}$ cascade in mediating the effects of thyrotropin and iodide on hormone synthesis and secretion in human thyroid slices. J Clin Endocrinol Metab 1994;79:152-9.

41. Wolff J. Excess iodide inhibits the thyroid by multiple mechanisms. Adv Exp Med Biol 1989;261:211-44.

42. Gartner R, Dugrillon A, Bechtner G. Evidence that thyroid growth autoregulation is mediated by an iodolactone. Acta Med Austriaca 1990;17(suppl 1):124-6.

43. Dugrillon A, Gartner R. Delta-lodolactones decrease epidermal growth factor-induced proliferation and inositol-11,4,5triphosphate generation in porcine thyroid follicles - possible mechanism of growth inhibition by iodide. Eur J Endocrinol 1995; 132:735-43.

44. Boeynaems JM, van Sande J, Dumont JE. Which iodolipids are involved in thyroid in thyroid autoregulation: iodolactones or iodoaldehydes? Eur J Endocrinol 1995;132:733-4.

45. Pereira A, Braekman JC, Dumont JE, Boeynaems JM. Identification of a major iodolipid from the horse thyroid gland as 2-iodohexadecanal. J Biol Chem 1990;265:17018-25.

46. Nilsson M. Actions of epidermal growth factor and its receptor in the thyroid. Trends Endocrinol Metab 1995;6:17582.

47. Pedrinola F, Rubio I, Santos CL, Medeiros-Neto G. Over expression of epidermal growth factor and epidermal growth factor-receptor mRNAS in dyshormonogenetic goiters. Thyroid 2001;11:15-20.

48. Taylor AH, Millatt LJ, Whitley GS, Johnstone AP, Nussey SS. The effect of basic fibroblast growth factor on the growth and function of human thyrocytes. J Endocrinol 1993;136:339-44.

49. Logan A, Black AG, Gonzales AM, et al. Basic fibroblast growth factor: an autocrine mitogen of rat thyroid follicular cells. Endocrinology 1992;130:2363-72.

50. Becks GP, Logan A, Phillips ID, Wang JF, Smith C, DeSousa $D$, et al. Increase of basic fibroblast growth factor (FGF) and FGF receptor messenger RNA during rat thyroid hyperplasia: temporal changes and cellular distribution. J Endocrinol 1994:142:325-38

51. Hoelting $T$, Siperstein AE, Clark OH, Duh QY. Epidermal growth factor enhances proliferation, migration and invasion of follicular and papillary thyroid cancer in vitro and in vivo. J Clin Endocrinol Metab 1994;79:401-8.

52. Westermark K, Karlsson FA, Westermark B. Epidermal growth factor modulates thyroid growth and function in culture. Endocrinology 1983;112:1680-6.

53. Duh QY, Gum ET, Gerend PL, Raper SE, Clark OH. Epidermal growth factor receptors in normal and neoplastic thyroid tissue. Surgery 1985;98:1000-7.

54. Roger PP. Thyrotropin-dependent transforming growth factor beta expression in thyroid gland. Eur J Endocrinol 1996:134:269-71.

55. Hoelting $T$, Zielke A, Siperstein AE, Clark OH, Duh OY. Transforming growth factor-beta 1 is a negative regulator for differentiated thyroid cancer: studies of growth, migration, invasion, and adhesion of cultured follicular and papillary thyroid cancer cell lines. J Clin Endocrinol Metab 1994;79:806-13.

56. Jasani B, Wyllie FS, Wright PA, Lemoine NR, Williams ED, Wynford-Thomas D. Immunocytochemically detectable TGF $\beta$ associated with malignancy in thyroid epithelial neoplasia. Growth Factors 1990;2:149-55.

57. Lazzereschi D, Ranieri A, Mincione G, Taccogna S, Nardi F Colletta G. Human malignant thyroid tumors displayed reduced levels of transforming growth factor $\beta$ receptor type II messenger RNA and protein. Cancer Res 1997;57:2071-6.

58. Yuasa R, Eggo MC, Meinkoth J, Dillmann WH, Burrow GN lodide induces transforming growth factor beta 1 (TGF $\beta$ 1) mRNA in sheep thyroid cells. Thyroid 1992;141-5.

59. Minuto F, Barreca A, Del Monte P, Cariola G, Torre GC, Giordano G. Immunoreactive insulin-like growth factor I (IGF-I) and IGF-I-binding protein content in human thyroid tissue. $\mathbf{J}$ Clin Endocrinol Metab 1989;68:621-6.
60. Thompson SD, Franklyn JA, Watkinson JC, Verhaeg JM, Sheppard MC, Eggo MC. Fibroblast growth factors 1 and 2 and fibroblast growth factor receptor 1 are elevated in thyroid hyperplasia. J Clin Endocrinol Metab 1998;83:1336-41.

61. Eggo MC, Hopkins JM, Franklyn JA, Johnson GD, Sanders DS, Sheppard MC. Expression of fibroblast growth factors in thyroid cancer. J Clin Endocrinol Metab 1995;80:1006-11.

62. Goodman AL, Rone JD. Thyroid angiogenesis: endotheliotropic chemoattractant activity from rat thyroid cells in culture. Endocrinology 1987;121:2131-40.

63. Cocks HC, Thompson S, Turner FE, Logan A, Franklyn JA, Watkinson JC, et al. Role and regulation of the fibroblast growth factor axis in human thyroid follicular cells. Am J Physiol Endocrinol Metab 2003;285:E460-9.

64. Tuttle RM, Fleisher M, Francis GL, Robbins RJ. Serum vascular endothelial growth factor levels are elevated in metastatic differentiated thyroid cancer but not Increased by short-term TSH stimulation. J Clin Endocrinol Metab 2002;87:1737-42.

65. litaka M, Miura S, Yamanaka K, Kawasaki S, Kitahama S Kawakami $Y$, et al. Increased serum vascular endothelial growth factor levels and intrathyroidal vascular area in patients with Graves' disease and Hashimoto's thyroiditis. J Clin Endocrinol Metab 1998;83:3908-12.

66. Hay ID. Papillary thyroid carcinoma. Clin Endocrinol Metab North Am 1990;19:545-76.

67. Venkatesh YS, Ordonez NG, Schultz PN, Hickey RC, Goepfert $\mathrm{H}$, Samaan NA. Anaplastic carcinoma of the thyroid: a clinicopathologic study of 121 cases. Cancer 1990;66:321-30.

68. Belfiore A, La Rosa GL, Padova G, Sava L, Ippolito O, Vigneri $R$. The frequency of cold thyroid nodules and thyroid malignancies in patients from an iodine-deficient area. Cancer 1987;60:3096-102.

69. Mellemgaard A, From G, Jorgensen T, Johansen C, Olsen JH, Perrild $\mathrm{H}$. Cancer risk in individuals with benign thyroid disorders. Thyroid 1998;8:751-4.

70. Levi F, Franceschi S, La Vecchia C, Negri E, Gulie C, Duruz G, et al. Previous thyroid disease and risk of thyroid cancer in Switzerland. Eur J Cancer 1991;27:85-8.

71. dos Santos Silva I, Swerdlow AJ. Thyroid cancer epidemiology in England and Wales: time trends and geographical distribution. Br J Cancer 1993;67:330-40.

72. Pendergrast WJ, Milmore BK, Marcus SC. Thyroid cancer and thyrotoxicosis in the United States: their relation to endemic goiter. J Chronic Dis 1961;13:22-38.

73. Franssila K, Saxén E, Teppo L, Bjarnason O, Tulinius H, Normann $T$, et al. Incidence of different morphological types of thyroid cancer in the Nordic countries. Acta Pathol Microbiol Scand [A] 1981;89:49-55.

74. Williams ED, Doniach I, Bjarnason O, Michie W. Thyroid cancer in an iodide rich area: a histopathological study. Cancer 1977;39:215-22.

75. Goodman MT, Yoshizawa CN, Kolonel LN. Descriptive epidemiology of thyroid cancer in Hawaii. Cancer 1988;61:1272-81.

76. Sehestedt T, Knudsen N, Perrild H, Johansen C. lodine intake and incidence of thyroid cancer in Denmark. Clin Endocrinol 2006:65:229-33.

77. Farahati J, Geling M, Mader U, Mortl M, Luster M, Muller JG, et al. Changing trends of incidence and prognosis of thyroid carcinoma in lower Franconia, Germany, from 1981-1995. Thyroid 2004; $14: 141-7$

78. Gomez Segovia I, Gallowitsch HJ, Kresnik E, Kumnig G, Igerc I, Matschnig S, et al. Descriptive epidemiology of thyroid carcinoma in Carinthia, Austria: 1984-2001. Histopathologic features and tumor classification of 734 cases under elevated general iodination of table salt since 1990: population based age-stratified analysis on thyroid carcinoma incidence. Thyroid 2004; $14: 277-86$.

79. Burgess J, Dwyer T, McArdle K, Tucker P, Shugg D. The changing incidence and spectrum of thyroid carcinoma in Tasmania (1978-1998) during a transition from iodine sufficiency to iodine deficiency. J Clin Endocrinol Metab 2000;85:1513-7. 
80. Pettersson B, Coleman MP, Ron E, Adami HO. lodine supplementation in Sweden and regional trends in thyroid cancer incidence by histopathologic type. Int J Cancer 1996;65:13-9.

81. Galanti M, Sparen P, Karlsson A, Grimelius L, Ekbom A. Is residence in areas of endemic goiter a risk factor for thyroid cancer? Int J Cancer 1995;61:615-21.

82. Harach HR, Williams ED. Thyroid cancer and thyroiditis in the goitrous region of Salta, Argentina, before and after iodine prophylaxis. Clin Endocrinol 1995;43:701-6.

83. Lind $P$, Langsteger W, Molnar M, Gallowitsch HJ, Mikosch $P$, Gomez I. Epidemiology of thyroid diseases in iodine sufficiency. Thyroid 1998;8:1179-83.

84. Franceschi S. lodine intake and thyroid carcinoma - a potential risk factor. Exp Clin Endocrinol Diabetes 1998;106:38-44.

85. Teng W, Shan Z, Teng X, Guan H, Li Y, Teng D, et al. Effect of iodide intake on thyroid diseases in China. N Engl J Med 2006;354:2783-93.

86. Camargo RYA, Tomimori EK, Neves SC, Knobel M, MedeirosNeto G. Prevalence of chronic autoimmune thyroiditis in the urban area neighboring a petrochemical complex and a control area in São Paulo, Brazil. Clinics 2006;61:307-12.
87. Saxén E, Franssila K, Bjarnason O, Normann T, Ringertz N. Observer variation in histologic classification of thyroid classification. Acta Pathol Microbiol Scand [A] 1978;86A:483-6.

88. Duntas LH. The role of selenium in thyroid autoimmunity and cancer. Thyroid 2006;16:455-60.

89. Rayman MP. Selenium in cancer prevention: a review of the evidence and mechanism of action. Proc Nutr Soc 2005;64:527-42.

\section{Address for correspondence:}

Meyer Knobel

Thyroid Unit, Division of Endocrinology and Metabolism

Hospital das Clínicas, University of São Paulo Medical School Av. Dr. Enéas Carvalho de Aguiar 155, 8 A, bl 3, PAMB

05403-900 São Paulo, SP

Fax: (1 1) 3069-7970

E-mail: meyer.knobel@hcnet.usp.br 